\title{
原著
}

\section{ヒト唾液の糖含有量の高い糖タンパク画分の 分離とそのレクチンに対する親和性}

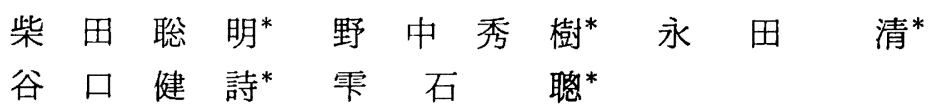

\begin{abstract}
概要：ヒト唾液に存在する糖含有量の高い糖タンパク画分の㗚造と, その機能に関する研究は極めて 少ない。私達は既に, ヒト耳下腺唾液よりこの糖タンパク画分を純化し, その糖鎖構造を解析したとこ ろ，䊀鎖中に $\alpha 1 \rightarrow 2$ マンノシド結合をもち，非還元末端に，フコース $\alpha 1 \rightarrow 2$ ガラクース $\beta 1 \rightarrow 3$ or $4 \mathrm{~N}$-アセチルグルコサミンの存在を確認した。一方，コンカナバリン A (Con A) は, $\alpha$-マンノー スに強い親和性をもっことから、この糖タンパクもC Con A と結合することが, その構造から推察され る。そこで, この事実を実験的に確認するとともに, 抗 $\mathrm{A}$, 抗 $\mathrm{B}$ 血清およびレクチンHとの結合性につ いても血球凝集阻止反応により追究した。

ヒト耳下腺唾液は，9名の健康な成人より水冷下で耳下腺開口部より直接採取した。この試料をセフ アデックス G-200により分画したところ，抗 $\mathrm{A}$ ，抗 B血清掞よびレクチンHに强い反応をもつ糖タンパ ク画分, 糖の含有量が高く, レクチン $\mathrm{H}$ のみに反応する糖タンパク画分とさらに, 抗 $\mathrm{A}$, 抗 B血清扰よ びレクチンHのいずれにも反応しない殆んどタンパクのみの画分の 3 画分が得られた。この糖の含有量 が高い糖タンパクの一部を, Con A-セファロースカラムに吸着させたところ, 非吸着画分に糖タンパ クは認められす゚，強い親和性を示すことが判明した。さらに吸着した糖タンパクは， $\alpha$ ママンノピラノシ ドにより脱着された。この性質は， $\mathrm{ABO}$ 式血液型のいずれの血液型においても同じであった。さらに， この糖タンパクの精製標品を電気泳動したところ, Cationic な電気泳動において, 1 つの不鮮明なバ ンドとして認められた。以上のことから，糖含有量の高い糖タンパクは，Con A-セファロースにより 効果的に，ほぼ単一に取り出された。なお，この精製標品はレクチンHに結合することが示された。

構成糖について調べてみると, 血液型による差異はなく, フコース：マンノース：ガラクトース：Nアセチルグルコサミンの相対比は, $2: 3: 3: 4$ であった。

本研究は, 喠液糖タンパクのなかでも, 糖含有量の高い㜍タンパク画分を, Con A-セファロースア フィニティカラムを応用して，効果的に分㕍できることを示し，この糖タンパクは Con A のみでな く, レクチンHに対しても强い親和性をもつことから, フコース $\alpha 1 \rightarrow 2$ ガラクトース $\beta 1 \rightarrow 3$ or 4 N-アセチルグルコサミンの櫵造が存在することを間接的に明らかにした。
\end{abstract}

\section{緒言}

唾液の糖タンパクは，エメナル僙表面に形成される攃 得被膜の構成成分であり，歯垢の基質形成に重要な役割 を果していると考えられる122。 そのほか唾液のもつ血
液型活性や, 菌凝集活性, さらに免疫学的活性などの発 現にも関与している。なかでも糖含有量の高い糖タンパ ク（プロリンーリッチ糖タンパクとも呼称されている。） 画分は, Hay ら8)によれば, 燐酸カルシウムの沈殿の 阻害因子として働くといわれている。この糖タンパク画

* 大阪大学歯学部予防歯科学教室 (主任: 常光旭教授)

* Department of Preventive Dentistry, Osaka University Dental School (Director: Prof. Akira TSUNE. MITSU)

昭和53年 7 月 15 日受付 
分は, 口腔内の生理的および病理的過程に, 重要な倸り をもつと考えられ近年注目をあびてきた。しかしながら， その構造と機能に関してはまだよく知られていない。

著者らは既に, ヒト耳下腺唾液より，この糖含量の高 い梼タンパク画分を, Friedman らの方法》に準拠して， セファデックス G-200ゲル滤過，CM-セルロースカラム クロマトグラフィーを組合せて分離抽出し，その糖側鎖 の構造を，メチル化，過ヨウ素酸酸化および種々のグリ コシダーゼによる加水分解などを組合せて，ガスクロマ トグラフ質量分析法を用いて解析し以下の上うな推定構 造を得た ${ }^{5)}$ 。

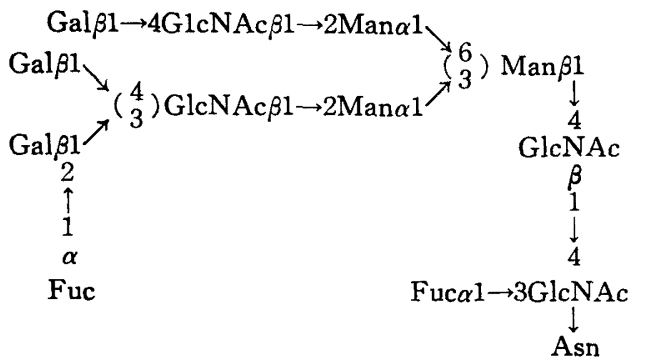

コンカナバリン A (Con A) は, ジャック豆より単離 された血球疑集タンパクであり，赤血球を凝集するだけ ではなく，多くの多糖や，糖タンパクと結合するレクチ ンであることはよく知られている6)。その結合能力に関 しては Goldstein らすにより詳細に報告され, Con A と 糖の結合に関与するのは，マンノピラノシドまたはグル コピラノシドまたはグルコピラノシドの C-3, C-4, C-6 位の水酸基であり， $\alpha$-マンノピラノシドや， $\beta$-グルコピ ラノシドに強く結合することが示されている。

上記の推定構造にみられるように，七卜唾液より抽出 した糖含有量の 極めて 高い糖タンパクの 糖鎖中心部に は， $\alpha$-マンノピラノシド結合が存在することから，当然 Con A との親和性が推察されるし，更に，オリゴ糖末 端にフコース $\alpha 1 \rightarrow 2$ ガラクトース $\beta 1 \rightarrow 3$ or $4 \mathrm{~N}$-ア セチルグルコサミンの構造がみられることから, 血球疑 集物質であるしレクチンHに対しても反応する可能性が ある。

本研究では，まずヒト耳下腺唾液糖タンパクを，セフ アデックス G-200を用いて分画し，糖含量の比較的高い 画分を取り出し，この画分が Con A と結合することを 確認した。引続いて, Con A-セファロースによるアフ ィニティクロマトグラフィーを用いて，棰液より糖含量 のきわめて高い糖タンパクの分離抽出を試みた。この際， 分離操作と平行して, 血球凝集阻止反応により糖タンパ クに対するレクチン $\mathrm{H}$ と結合性を, $\mathrm{ABO}$ 式血液型,
分泌型，非分泌型との関連性において同時に追究した。

\section{実験材料ならびに方法}

(1) 唾液採取

年齢 $20 \sim 30$ 歳の健康な男性 9 名より, 甘味ガム刺激下 で耳下腺開口部より Keene の方法 ${ }^{8)}$ により採取した。被 験者 1 人より約 $100 \mathrm{ml}$ の棰液を採取し，血液型活性を $\mathrm{A}$ 型(分泌型), B型(分泌型), $\mathrm{O}$ 型(分泌型)および $\mathrm{A}$ 型(非 分泌型）とにわけ，採取した唾液は氷泠下で保存した。

（2）唾液中の血液型活性の判定

各個人の唾液の血液型は，血球凝集阻止反応により判 定した。この反応に用いた血球掞よび血球凝集物質は次 の通りである。A型，B型およびH型の血球は，P.B.S. (Phosphate Buffered Saline) $\mathrm{pH}$ 7.0により 3 回洗浄 し，その後 $\mathrm{A}$ 型扰よび $\mathrm{B}$ 型は同緩衡液に $2 \%, \mathrm{H}$ 型は 1 \%濃度になるように血球浮遊液を調整した。A型および B型の血球凝集物質は，ヒト由来の抗血清 (DADE Division. American Hosp. Supply Corp. Miami, Flo., U.S.A.)を，H型はレクチンH (DADE Division. American Hosp. Supply corp. Miami, Flo., U.S.A) を使 用した。血液型活性は，2 倍連続稀釈法により，凝集を 阻止する最大稀䣋倍数を血球凝集物質の力価と対比させ 判定した。

（3）ディスク電気泳動

電気泳動は, Reisfeld の方法9"に準じて，10\%の Cationic なポリアクリルアミドゲルを支持体として行なっ た。ゲル $(0.4 \times 10 \mathrm{~cm})$ をガラスカラム調整し，アラニ ン緩衝液 $\mathrm{pH} 4.5$ を用い $4 \mathrm{~mA} /$ tube の条件下で 3 時間 電気泳動を行なった。同時に, Davis の 方法(10)に準じ Anionic な方法による電気泳動も行なった。タンパク は，アミドブラック10B を用いて検出した。

\section{(4) 構成糖の測定}

精製した糖タンパク $0.8 \mathrm{mg}$ を $4 \mathrm{~N}$ トリフルオール酢 酸で $100^{\circ} \mathrm{C} 5$ 時間加水分解し, ベーパーミックスによる 減圧下でトリフルオール酢酸を除去, $\mathrm{NaBH}_{4}$ により糖 の還元を行なった。アセチル化は, $0.5 \mathrm{ml}$ の無水酢酸で $100^{\circ} \mathrm{C} 2$ 時間行ない, 減圧乾固の後アセチル化糖をク口 ロホルムにより抽出した。検出は, 島津ガスクロマトグ ラフ GC-4CMPF 型㧍よび日立056型記録計を用いた。 中性糖は，3\% ECNSS-M（ガスクロ工業株式会社） を充媜した $2 \mathrm{~m}$ ガラスカラムを用い， $190^{\circ} \mathrm{C}$ で恒温分 析を行なった。アミノ糖は， $1.5 \%$ ov-17 (和光純薬工 業株式会社)を充埧した $1 \mathrm{~m}$ ガラスカラムを用い, $150^{\circ} \mathrm{C}$ より $205^{\circ} \mathrm{C}$ まで毎分 $1^{\circ} \mathrm{C}$ の昇温分析を行なった。標 
準試料としてフコース，マンノース，ガラクトースおよ びN-アセチルグルコサミン各等モル同様の処理により アセチル化し，同一条件でガスクロマトグラフィを行な った。

(5) 糖およびタンパクの定量

総ヘキソース量は，フェノール硫酸法11により，また シアル酸は, Warren のチオバルビツール酸法122に従っ て測定した。タンパクは，波長 $230 \mathrm{~nm}$ の吸収によりモ ニターするとともに Lowry らの方法を改良した Hartree の方法 ${ }^{13)}$ で定量した。標準試料としてへキンース には D-グルコース，シアル酸は N-アセチルノイラミン 酸,タンパクは牛血清アルブミン (再結晶, Sigma. Co., St. Louis, Mo., U.S.A.) を用いた。

\section{実験結果}

（1）糖含有量の高い糖タンパク画分の Con A との親 和性ならびに同画分の Con A-セファロースによる分離 ・精製

唾液の 20 80\%飽和硫酸アンモニウム塩析により得ら れた画分を, $0.05 \mathrm{M}$ 重炭酸アンモニウム緩衝液 $\mathrm{pH}$ 7.8 亿溶解し，透析脱塩後あらかじめ同緩衝液で平衡化 したセファデックス G-200によりゲル滤過を行ない， Fig. 1 に示す結果を得た。即ち，波長 $280 \mathrm{~nm}$ に強い吸 収が認められほぼ Void-volumeに流出される画分 (Fraction-I)，280nm の吸収は弱いが糖，タンパクを含 む画分（Fraction-II）およびそれより遅く流出する殆ん どタンパクのみの画分 (Fraction-III) が得られた。こ の中より糖含有量の高い (Fraction-II) を凍結乾燥によ り濃縮し，0.05M P.B.S., pH 7.0で一夜透析した標品 を用いて Con A との結合について検討した。吸着実験 には，あらかじめ上記緩衝液で平衝化した Con A-セフ アロース (Pharmacia Fine Chem., Uppsala, Sweden) を充媜したカラム $(2 \times 20 \mathrm{~cm})$ を用い，上記標品の一部 (ヘキソースで $1 \mathrm{mg}$ 量) を用いて吸着を試みた。Fig. 2 亿示されるように，吸着しない画分（Peak-I）におい ては230nm による吸収が認められるが，糖成分はほと んど認められなかった。さらに Con A-セファロースカ ラムに吸着した画分（Peak-II）を $50 \mathrm{mM} \alpha$-メチルマン ノシドにより脱着を試みたところ，糖成分の約 $90 \%$ 近く が脱着された(Table 1)。このことから,Fraction-IIに含 まれる耳下腺唾液糖タンパクは，Con A-セファロース の内でも，特に Con A に結合していたことがわかる。 脱着された画分 (Peak-II) をさらに濃縮, 蒸留水によ る透析後, $\alpha$-メチルマンノシドを除くために Bio-gel P2
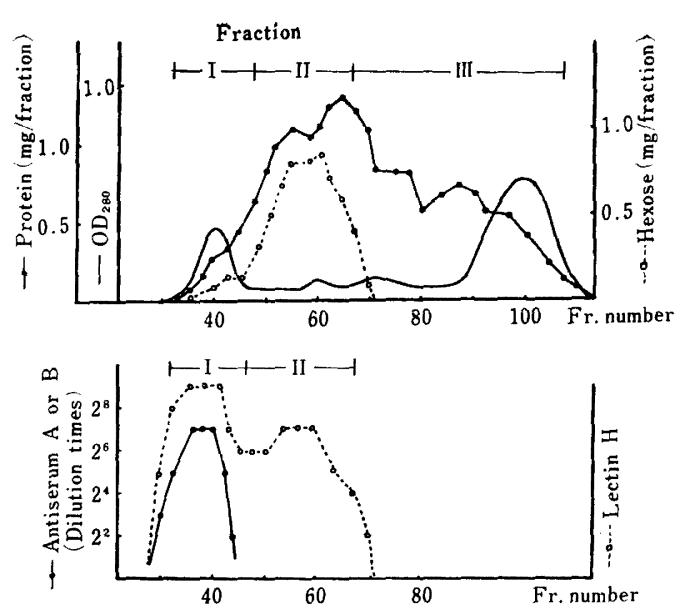

Fig. 1 Gel filtration of the concentrated saliva on Sephadex G-200. $2.5 \mathrm{ml}$ fractions were collected. The upper figure shows the patterns of protein and hexose and the lower indicates the activities of hemmaglutination inhibition of antiserum or Lectin $\mathrm{H}$ by each fraction, respectively.

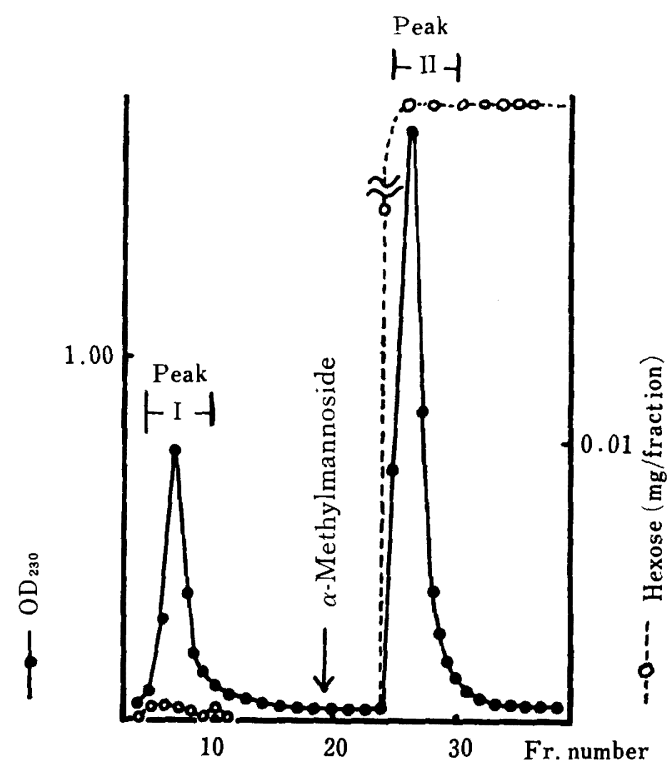

Fig. 2 Affinity chromatography of Fraction II on Con A-Sepharose.

によりゲル濾過を行ないFig. 3 に示すような結果を得 た。

以上の上らな操作により唾液の糖含有量の高い糖タン 
Table 1 Isolation procedures of salivary glycoprotein from persons of blood group $A$

\begin{tabular}{lcc}
\hline \multicolumn{1}{c}{ Fraction } & $\begin{array}{c}\text { protein } \\
(\mathrm{mg})\end{array}$ & $\begin{array}{c}\text { Hexose } \\
(\mathrm{mg})\end{array}$ \\
\hline $\begin{array}{l}\text { Parotid saliva } \\
\text { Gel filtration on Sephadex }\end{array}$ & 202 & 17.6 \\
$\begin{array}{l}\text { G-200 (Fraction- II) } \\
\text { Con A-Sepharose* }\end{array}$ & 31.4 & 9.68 \\
$\begin{array}{l}\text { Unadsorbed (peak- I ) } \\
\text { Adsorbed and eluted } \\
\text { with 50 mM } \alpha \text {-methyl- } \\
\text { mannoside (peak- II) }\end{array}$ & 0.75 & N.G. \\
\hline
\end{tabular}

* One mg, in regard to hexose, from Fraction II was applied.

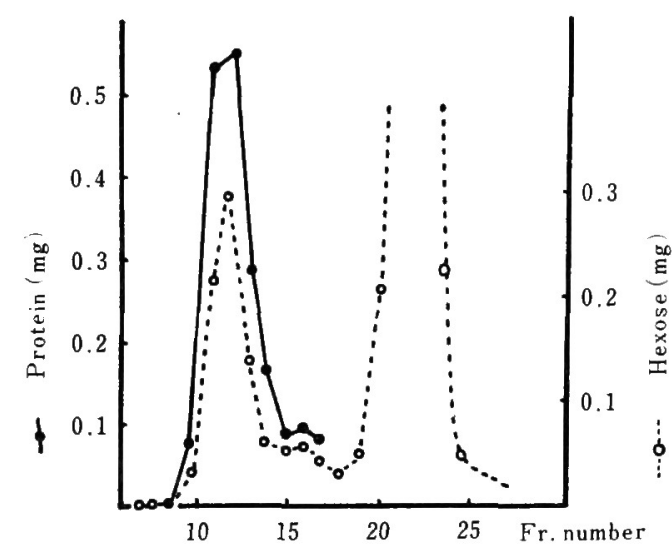

Fig. 3 Gel filtration of peak II on Bio-Gel P2.

Hemagglutination inhibition against Lectin $\mathrm{H}$ was found in fractions number 11,12 and 13 .

パク画分の 分離精製が 可能であることがわかった。即 ち，ゲル濾過後 Con A-セファロースによるアフィニテ イクロマトグラフィにより，非常に効果的に精製出来 た。その精製過程を各段階についてみると Table 1 に 示す通りである。なおいずれの血液型においても，唾液 のセファデックス濾過のパターン，および Con A-セフ アロースアフィニティクロマトグラムの様態はほぼ同じ であった。また精製標品は，アクリルアミドによるディ

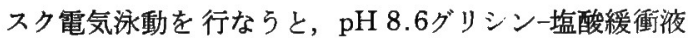
を用いた Davis の方法では移動は見られず， pH 4.5 アラニン緩衝液を用いた Reisfeld の方法において陽極 に近、部分にややブロードなバンドとして確認された (Fig. 4)。なお， アクリルアミドゲルを細かく切断し， それぞれの細片について分析したところ，このブロード

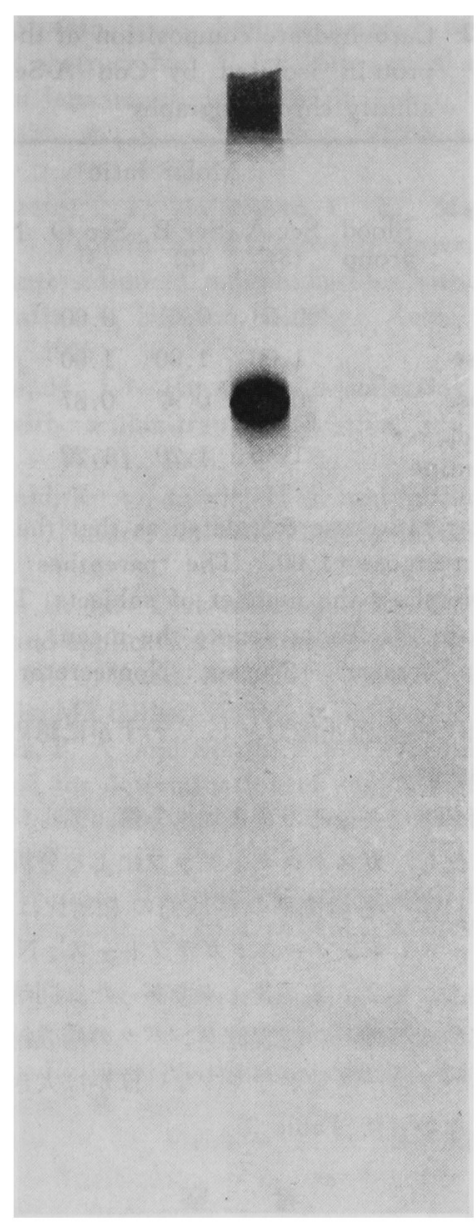

Fig. 4 Electrophoretic pattern of the purified sample.

なバンドの所にのみ糖を検出した。

（2）血液型物質に対する抗血清およびレクチンHとの 反忍

A型，B型抗血清およびレクチンHを用いた血球凝集 阻止反応に上る血液型活性は Fig. 1 およびFig. 3 にみ られる通りである。セファデックス G-200を用いたゲル 滤過の結果, A型捄よびB型血液型活性は, Fraction-I においてのみ認められ，H型は，Fraction-I において 糖, タンパク含有量が低いにもかかわらず強い活性が認 められ, Fraction-II に抒いて Fraction-I よりタンパ ク比活性が弱いながら認められた。Con A アフィニテ ィクロマトグラフィにより精製した糖タンパクにも同様 に，H型に対して血球凝集阻止反応が認められた（Fig. 3)。今回用いた非分泌型 $\mathrm{A}$ 型唾液においては，血液型 活性は非常に弱く, A 型抗血清およびレクチンHに対し, 
Table 2 Carbohydrate composition of the glycoprotein isolated by Con A-Sepharose affinity chromatography

\begin{tabular}{|c|c|c|c|c|c|}
\hline \multirow{2}{*}{ Sugar } & \multicolumn{5}{|c|}{ Molar ratio* } \\
\hline & $\begin{array}{l}\text { Blood } \\
\text { group }\end{array}$ & $\begin{array}{l}\text { Sec } A \\
(3)\end{array}$ & $\underset{(2)}{\operatorname{Sec} B}$ & $\underset{(3)}{\mathrm{Sec} O}$ & $\underset{\text { (1) }}{\text { Nonsec A }}$ \\
\hline Fucose & & 0.58 & 0.61 & 0.60 & 0.41 \\
\hline Mannose & & 1.00 & 1.00 & 1.00 & 1.00 \\
\hline Galactose & & 0.98 & 0.97 & 0.87 & 0.99 \\
\hline $\begin{array}{l}\text { N-Acetyl- } \\
\text { glucosamine }\end{array}$ & & 1.45 & 1.20 & 1.22 & 1.30 \\
\hline
\end{tabular}

* Molar ratio was calculated as that the moles of mannose $=1.00$. The parenthes in the Table show the number of subjects. The values in the Table denote the mean.

Sec: Secretor Nonsec: Nonsecretor

$2^{-6}$ 倍以下の凝集阻止能力としてわずかに認められた。

(3) 構成糖

精製糖タンパクをそのまま加水分解，アルジトールア セテート化し，ガスクロマトグラフによる分析の結果,

A， B， O型の各糖側鎖の 構成糖の相対比はほぼ等し く,フコース:マンノース:ガラクトース:N-アセチル グルコサミン = $2: 3: 3: 4$ であった。同時に行なっ た非分泌型 $\mathrm{A}$ 型唾液の精製糖タンパクの構成糖は, 分泌 型にくらべフコース量がやや少ないほかは大きな差異は 認められなかった(Table 2)。

\section{考察}

ヒト耳下腺唾液の糖タンパクを, 七ファデックス G200を用いて分画してみると, 抗 A, 抗 B血清, レクチ ンHいずれに対しても親和性をもつ画分がまず䲣出し てくる。次いでレクチンHのみに親和性をもつ糖含有 量の高い糖タンパク 画分が得られ，最後にいずれの型 物質にも反応しない殆んどタンパクのみの画分が濾出 してくる。このレクチンHのみに反応する画分が，私達 が Friedman らの分画法年によって得た糖含有量の高い 糖タンパクと同一のものであるならば，この画分は $\alpha$ マンノピラノシドに強い親和性を示す筈である。そこで 実験的に Con A に対する反応性を調べてみると,この 糖タンパク画分は Con A に強く結合した。従ってこの 性質を利用して，唾液の糖タンパクのなかでも糖含有量 の高い糖タンパク画分をCon A-セファロースアフィニ ティクロマトグラフィによって分潅してみたところ, 非 常に効果的に收率よく精製することができた。この精製 標品は，Cationic なポリアクリルアミドゲル電気泳動
法により diffuse ながら均一であり Anionic なポリア クリルアミドゲルは泳動されないことから，強い塩基性 の糖タンパクであることが確かめられた。また，精製標 品の構成糖は, フコース, マンノース, ガラクトース, N.アセチルグルコサミンで, その相対比は $2: 3: 3$ : 4 であり, 著者らが Friedman 分画法()で得たものの構 成糖の種類と，その相対比ともよく一致した。緒言にお いて述べた如く，オリゴ糖末端に，フコース $\alpha 1 \rightarrow 2$ ガラ

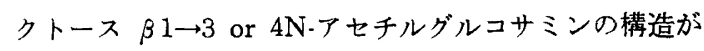
あれば，血球凝集物質レクチンHが結合することはよく 知られている。Con A-セファロースアフィニティカラ ムクロマトグラフィを利用して得られた精製標品と、レ クチンHが強く結合することからこの標品は, 上記の糖 鎖構造をもつオリゴ糖タンパクであると考えられる。こ のような実験結果を, 総合的に勘案すると, 本実験で精 製した糖タンパク標品は, 既に私達が構造解析した糖含 有量の高い糖タンパクと同一のものである可能性は極め て高いと言える。

アフィニティクロマトグフィで得た精製標品の構成糖 比には, 分泌型 $\mathrm{A}, \mathrm{B}, \mathrm{O}$ 型血液型による差異は認めら れなかったが, 本研究に供した非分泌型 $\mathrm{A}$ 型のもの一例 については, 構成糖においてフコース量が分泌型のもの よりやや少なく, レクチン Hに対する血球凝集阻止能力 は極めて低かった。しかし，少量のシアル酸が見出され ることなどからミクロヘテロジェナイティの混在が考え られるので, 非分泌型のものについては今後例数を增や して再検討する必要があると思われる。

最近 Smith ら ${ }^{14)}$ は, S. mutans 6715-49がレクチン 様物質を産出すると述べ，唾液糖タンパクとの相互反応 を示唆する報告を行なっている。

私達は, S. mutans BHT 株を用い, 合成培地と, 天 然培地にそれぞれ培養後, 菌体表面に附着する唾液糖夕 ンパクの存在を血球凝集阻止反応により確認する成績を 得たが，この所見は Gibbons ら る。レクチン様物質と, 喠液糖タンパクの口腔内細菌を 介した相互反応について詳細な解析を現在進めている。

\section{結 論}

（1）ヒト耳下腺唾液の糖タンパクを，セファデックス G-200を用いて分画すると，抗 A, 抗 B および゙レクチン H、ずれに対しても反応する糖タンパク画分, レクチン Hのみに反忘する糖含有量の高い糖タンパク画分と,さ らに抗 A, 抗B血清およびレクチンHいずれにも反応し ない殆んどタンパクのみの画分の 3 画分が得られた。 
（2）レクチンHのみに反応する糖含有量の高い糖タン ヘク画分は, Con A によく結合することから，この性 賈を利用して Con A-セファロースアフィニティカラム クロマトグラフィーによって，この糖タンパク画分を有 动的に，しかも收率よく唾液より分離精製することがで き。

（3）この精製標品の構成糖は，フコース，マンノー ス,ガラクトース, N-アセチルグルコサミンで, その相 㣙比は $2: 3: 3: 4$ であった。この相対比は分泌型 A， B，O血液型の違いによる差異は認められなかっ t。

（4）この精製標品は, 分泌型 A, B, O血液型に関倸 なくレクチン $\mathrm{H}$ と強い親和性を示した。

本研究の遂行にあたり，御助言を賜わった大阪市立大 学生活科学部三崎 旭教授に感謝します。なお，サンス ター歯磨株式会社より研究費の一部をご援助していただ いたことを附記し，お礼申し上げます。

\section{文献}

1) Leach, S. A : In “Dental Plaque", W. D. Mchugh ed., E. \& S. Livingstone, Edinburgh, 143-156, 1970.

2) 中村 亮, 常光 旭：喠液のグリコプロティン, 国際歯科ジャーナル，2:515-526, 1975.

3) Hay, I and Belensz, D.: Identification of Human Anionic Proline-Rich Proteins as Inhibitors of Calcium Phosphate Precipitation, J. Dent. Res., 56 : Special issue A 61, 1977.

4) Friedman, R. D., Donald Merritt, A. and Bixler, D.: Immunological and chemical composition of heterogeneous basic glycoprotein in human parotid saliva, Biochem. Biophys. Acta., $230: 599-602,1971$.

5) Shibata, S., Nakamura, R., Tsunemitsu, A. and Misaki, A.: Tne structure of major glycoprotein from human parotid saliva, IADR abstruct No. 37 for 25th annual meeting of Japanese division IADR Tokyo, 1977.

6) 大沢利昭, 森 良一：レクチン, 講談社サイエ ンティフィク, 1975.

7) Goldstein, I. J,. Hollerman, C. E., Merric, J. M. : Protein carbohydrate interaction, I . The interaction of polysaccharides with concanavaline A, Biochen. Biophys. Acta., 97 : 68-76, 1965.

8) Keene, H. J. : Parotid fluid collection system with vacuum-trap modification, J. Dent. Res., $42: 1041,1963$.

9) Reisfeld, R. A., Lewis, U. J. and Williams, D. E. : Nature, No. 4838 ; 281-283, July 21, 1962.

10) Davis, B. J.: Disk electrophoresis-II, Method and application to human serum protein, Ann. N. Y. Acad. Sci., 121: 404-427, 1964.

11) Dubois, M., Gilles, K. A., Hamilton, J. K., Rebers, P. A. and Smith, F.: Colorimetric method for determination of sugars and related substances, Analyt. Cnem., $28: 350-$ 356, 1959.

12) Warren, L.: The thiobarbituric acid assay of sialic acids, J. Biol. Chem., $234: 1971-$ 1975, 1959.

13) Hartree, E. F. : Determination of protein, A modification of the Lowry method that gives a linear photometric response, Analyt. Biochem., $48: 422-427,1972$.

14) McCabe, M. M., Hamelik, R. M. and Smith, E. E. : Purification of dextran-binding protein from cariogenic streptococcus mutans, 78 : No. 1, 1977.

15) Gibbons, R. J. and Quershi, V.: In M. Stiles, W. Loesch and T. ŌBreien, : Microbiological Aspect of Dental Caries, 1 ; 163181, Information Retrieval, Inc., Washington, D. C., 1976. 


\begin{abstract}
Interaction of Carbohydrate-rich Glycoprotein from Human Parotid Saliva with Concanavalin A and Lectin H from Ulex europeus, Satoaki SHIBATA*, Hideki NONAKA*, Kiyoshi NAGATA*, Tateshi TANIGUCHI* and Satoshi SHIZUKUISHI*. Our previous study proposed the structure of the oligosaccharide chain in carbohydrate-rich glycoprotein (Proline-rich glycoprotein) from human parotid saliva as follows :
\end{abstract}

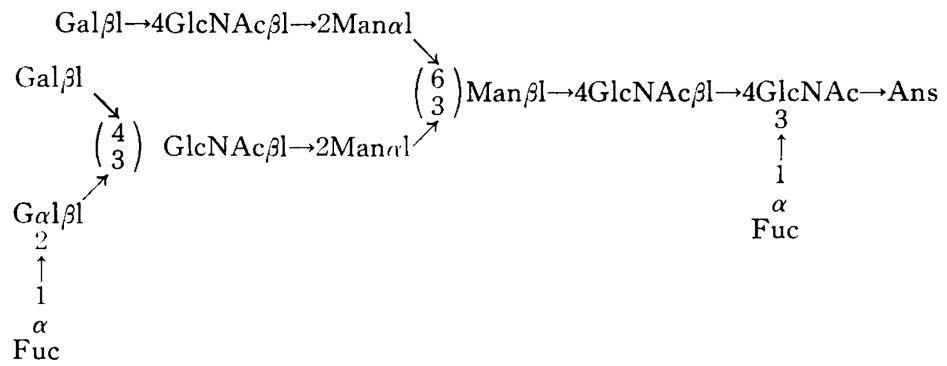

There are $\alpha$-mannoside and Fuc $\alpha \mathrm{l} \rightarrow 2 \mathrm{Gal} \beta \mathrm{l} \rightarrow 3$ or GlcNAc chains in the proposed structure. It is well known that concanavalin $\mathrm{A}$ (Con $\mathrm{A}$ ) reacts to $\alpha$-mannoside, and that lectin $\mathrm{H}$ binds to Fuc $\alpha 1 \rightarrow 2 \mathrm{Gal} \beta \mathrm{l} \rightarrow 3$ or $4 \mathrm{GlcNAc}$ chains. This study was therefore designed to confirm the interaction of carbohydrate-rich glycoprotein isolated from human parotid saliva with Con A and/or lectin $\mathrm{H}$ from Ulex europeus.

Parotid saliva samples were obtained from nine healthy men, ranging in age from 20 to 30 , 8 of whom were secretors of blood groups $\mathrm{A}, \mathrm{B}$, or $\mathrm{O}$ and one of whom was a non-secretor of blood group A. Serological activity of the samples was assayed by the hemagglutination inhibition test using microtiter plates. The fraction containing small amount of carbohydrate was isolated by gel filtration of the saliva which was fractionated with $20-80 \%$ ammonium sulfate. The blood group substances of $\mathrm{A}, \mathrm{B}$, and $\mathrm{H}$ were completely excluded from the fraction by this step. Then an aliquot of this fraction was applied to the column packed with Con A-Sepharose in order to determine the affinity of glycoprotein in the fraction to Con A. Most of the carbohydrate components were adsorbed onto the column. The adsorbed materials were eluted with $50 \mathrm{mM} \alpha$-methylmannoside. The glycoprotein eluted from Con A-Sepharose had a broad band when treated with cationic electrophoresis on acrylamide gel. The principal carbohydrate components were fucose, galactose, mannose, and $\mathrm{N}$-acetylglucosamine at the ratio of $2: 3: 3: 4$, which was the same as that of the proposed structure of glycoprotein. No significant change in ratio of carbohydrate components was observed among the different blood groups. These findings clearly indicate that the carbohydrate-rich glycoprotein reacts to Con A strongly, and that the Con A-Sepharose is available for the purification of carbohydrate-rich glycoprotein from saliva. The affinity of the salivary glycoprotein to Con A-Sephrose was not affected by the different serological activity of different persons. The carbohydrate-rich glycoprotein isolated from the secretor person by Con A-Sepharose column chromatography inhibited the hemmagglutination by lectin $\mathrm{H}$, but the glycoprotein from the non-secretor person did not show this effect. The results described here seem to support the proposed structure of carbohydrate-rich glycoprotein from human parotid saliva reported previously. 